\title{
Men who have Sex with Men
}

National Cancer Institute

\section{Source}

National Cancer Institute. Men who have Sex with Men. NCI Thesaurus. Code C84365.

Men who engage in sexual activity with other men, regardless of how they identify themselves. 